\title{
Regional Benches of the Supreme Court of India - The Path Ahead
}

\author{
Sankalp Mishra*
}

\section{Abstract}

There is a need for the establishment of regional benches of the Supreme Court. By the analysis of various statistical data, the paper puts forward the urgent need for widening the reach of the Supreme Court and also to rejuvenate and reestablish the tarnishing reputation of the Supreme Court as an ordinary court of appeal. The paper explores the essential reasons for the establishment of benches of Supreme Court that can be broadly divided into three heads namely (i) wide access to justice (ii) Supreme Court reduced to an ordinary court of appeal (iii) litigation as a measure of well-being. The paper also analyses the recommendations laid out in the $95^{\text {th }}, 120^{\text {th }}$, $125^{\text {th }}$ and $229^{\text {th }}$ Law Commission reports and analyses problem in hand, on the basis of analysis and the immediate need for the reform of the judicial system.

Keywords: Article 130 of the Constitution of India, Cassation Benches, Litigation, Justice, 95th \& 229th Report of the Law Commission.

\section{Introduction}

The Supreme Court in the case of V. Vasanth Kumar v. H. C. Bhatia ${ }^{1}$, decided to constitute a Constitution Bench to debate on the idea of

\footnotetext{
* Rajiv Gandhi School of Intellectual Property Law, IIT Kharagpur, India; sankalp01mishra@gmail.com.

${ }^{1}$ V. Vasanth Kumar v. H. C. Bhatia, (2016) 7 SCC 686
} 
National Court of Appeal2, which can give new wings to the perennial debate on the establishment of benches of the Supreme Court. The Apex Court is often arguably termed as the most powerful court in the world, because of the wide discretionary power wielded by it and its role in shaping the country's jurisprudence. But when we talk about the most powerful court, is it restricted to the power it envisages or does it also include the wide access to justice to its citizens? When the Supreme Court was formed, there was apprehension in the minds of the Constitution makers regarding the access to justice to all. The Constituent Assembly's will and spirit for promoting wide access, was clearly elucidated through the words of Pandit Thakur Das Bhargava, who argued that there should be liberalization of the jurisdiction, and that it should be seen in all fit and proper cases that the ordinary man gets full justice. ${ }^{3}$ Dr. B.R. Ambedkar, often referred to as the father of the constitution, labeled Article 32 as the heart and soul of the Constitution, as it provided the citizens the right to directly approach the court, in case of violation of fundamental rights. Without this article, the Constitution would be reduced to nullity. ${ }^{4}$ But on the other hand, there were few who were apprehensive about the wide discretionary power given to the court, to hear appeals. Biswanath Das had argued that the Constitution's provisions for interminable appeals from court to court would only serve to profit lawyers. He also raised the issue that if there is justice based on truthfulness of facts then it must be had in the preliminary court or in the subsequent appellate court. ${ }^{5}$ Contemplating on the words of Dr. B. R. Ambedkar, the prime purpose or goal of the Supreme Court is to deal with cases

${ }^{2}$ All you need to know about National Court of Appeal, The Hindu, Apr. 28, 2016, http://www.thehindu.com/news/national/national-court-ofappeal-the-hindu-explains/article8532094.ece.

3Statement by Pandit Thakur Das Bhargava, Constituent Assembly Debates, (June 3, 1949).

4Statement by Dr. Ambedkar, Constituent Assembly Debates, 953 (Dec. 9, 1948). Dr. Ambedkar, however did not seem to imagine that the Supreme Court would fully hear cases involving fundamental rights under its original jurisdiction, but rather that it could grant interim relief in appropriate cases.

5Statement by Biswanath Das, Constituent Assembly Debates, (June 6, 1949). 
involving substantial question of law or the interpretation of the Constitution. But over a period of time, because of the admissibility of the type of cases, it has reduced itself to a court of appeal. In the words of former Chief Justice of India, T.S. Thakur, 98\% of the estimated working time of the Supreme Court judges is supposedly wasted in dismissing such cases of appeal. ${ }^{6}$ Also, through empirical data it has been established that in 2011, of all the appeals to the Supreme Court, $34.1 \%$ of the cases represented only $7.2 \%$ of the total population in India. 7 Thus, the vision of the Constitution makers to provide wide access to all, stands on a futile ground. Moreover, the Supreme Court is suffering from serious backlog crisis. According to the data available, the Supreme Court of India disposed off 47,424 cases in the year 2015 in comparison to 45,042 in 2014 and 40,189 in the year 2013.In spite of the fast disposal of cases, the backlog in the Supreme Court still stands at a staggering figure of 59,468 cases, as of February 2016. ${ }^{8}$ Thus, looking at the various issues plaguing the functioning and integrity of the Supreme Court, this paper seeks to provide solution through the establishment of the benches of the Supreme Court, as suggested by the Law Commission, in various reports ${ }^{9}$ and also the recommendations of Parliamentary Standing committee on Law and Justice. ${ }^{10}$ The paper also puts forward the necessity for the establishment of the benches of the Supreme Court by looking into various criteria such as (i) access to justice (ii) types of cases to be instituted and the reducing size of the bench and (iii) litigation as a measure of well-being.

${ }^{6}$ All you need to know about National Court of Appeal, The Hindu, (April 28, 2016), http://www.thehindu.com/news/national/national-court-ofappeal-the-hindu-explains/article8532094.ece.

${ }^{7}$ Nick Robinson, A Quantitative Analysis of The Indian Supreme Court's Workload, http://www.cprindia.org/sites/default/files/articles/SSRNid2189181.pdf (last visited Apr. 25, 2017).

${ }^{8}$ Supra note 6.

${ }^{9}$ With special reference to the $229^{\text {th }}$ Law Commission Report which talks about the need for division of the Supreme Court into a Constitution Bench at Delhi and Cassation Benches in four regions at Delhi, Chennai/Hyderabad, Kolkata and Mumbai.

10Parliamentary Standing Committee on Law and Justice suggestions in the 2nd (2004), 6th (2005) and 15th (2006) and 20th (2007) Reports. 


\section{Recommendations of Law Commission and Parliamentary Standing Committee}

The law commission, over a period of time, has repeatedly stressed on the establishment of the benches of the Supreme Court in its various reports, to solve the issue of backlogs and provide wide access to justice to all. As early as in 1986, the Law commission in its 95 th report ${ }^{11}$ recommended the division of the Supreme Court into:

1. Constitutional division

2. Legal Division

The 95th Report unmistakably set down what kind of cases will fall under specific classifications. An example for the same could be the aforesaid division will apply after cases are analyzed with reference to the considerable questions of law with regard to the understanding of the Constitution, or any other matter identified with a request, or governed under the Constitution, or some other matter which may come under the ambit of Constitutional law. This division would take care of the various kinds of cases, especially Special Leave Petitions (SLPs), as provided for under Article 136 or such other provisions of the Constitution ${ }^{12}$. It was additionally prescribed, that judges appointed to the Supreme Court would, from the earliest starting point, be designated to a specific division.

The Law Commission in its $12^{\text {th }}$ report titled "The Supreme Court A Crisp Look"13 gave additional reasons for the classification of the Supreme Court and reiterated the suggestions put forth by the 95th Law Commission. In passage 4.17, the Commission raised the issue of wide access to justice, particularly to individuals originating from far-away places, as the Supreme Court sits at Delhi alone and

1195 th Law Commission Report available at http:/ /lawcommissionofindia.nic.in/51-100/report95.pdf (last visited on April 24, 2017).

${ }^{12} I d$.

13125 Law Commission Report available at http://lawcommissionofindia.nic.in/101-169/report125.pdf (last visited on April 24, 2017). 
those originating from inaccessible places need to spend an exorbitant amount of money to go to the Supreme Court. Likewise, the extra cost of bringing one's own legal counsel should also be noted. Further, as deferment is a repetitive marvel, it duplicates the expenses. In this manner, classification of Supreme Court into Constitutional Court and Court of Appeal or a Federal Court of Appeal would enable no genuine special case to be taken to the Federal Court of Appeal, sitting in Benches in different parts of India. This would extensively diminish costs and the legal counsel will have the benefit of his case being contended by a similar supporter who has helped him in the High Court and who may not be required to take off from his usual work. ${ }^{14}$

Besides realizing of the issue of deficiency of Judges, the $120^{\text {th Law }}$ Commission Report titled "Manpower Planning in Judiciary: A Blueprint"15, submitted in 1987, examined the judge to populace proportion in different purview. The proportion amongst judges and populace is 10.5 judges for every million. However, Shri Justice S. P. Bharucha, former Chief Justice of India, in his Law Day address in 2001, expressed this figure to be 12 or 13, while it is 75.2 per million in Canada, 107 for every million in USA, 41.6 for every million in Australia and 50.9 for every million in the United Kingdom. The Commission in its report prescribed that there was solid defense to expand the then existing proportion from 10.5 judges for each million to no less than 50 judges for every million of the Indian population. ${ }^{16}$ The 229th Law Commission Report titled "Need for division of the Supreme Court into a Constitution Bench at Delhi and Cassation Benches in four regions at Delhi, Chennai/Hyderabad, Kolkata and Mumbai"17, depending on the prior three Law Commission reports, laid down the foundation of the Benches of the Supreme Court, setting out the reason for the

\section{${ }^{14} I d$.}

15120th Law Commission Report, Manpower Planning in Judiciary: A Blueprint available at http://lawcommissionofindia.nic.in/101169/report120.pdf (last visited on April 24, 2017).

$16 I d$.

17229th Law Commission Report available at http:/ /lawcommissionofindia.nic.in/reports/report229.pdf(last visited on April 24, 2017). 
denied access to justice to individuals living far from Delhi. It also pointed out that the exchange cost that will be incurred for them having to travel from their local region to Delhi will adversely affect their right of entitlement to Justice as ensured by the Constitution. The Law commission also looked into the classification as present in countries like Italy and Egypt, where there are Courts of Cassation. The Law Commission considered the structure of different nations which mix the elements of cassation and Judicial review. Countries like Ireland, the United States of America and Denmark, follow this. With a view to reduce the overwhelming excess of cases in the higher courts and to meet the issue of discovering appropriate people for arrangement of judges in these courts, the retirement age for the Supreme Court and High Court Judges should be raised to 70 and 65 years, respectively. 18

The Parliamentary Standing Committee on Law and Justice, has every now and then recommended in its respective reports, that for wide access to justice and for diminishing the build-up, it is important to set up the seats of the Supreme Court contingent upon the local separation. In the second (2004), sixth (2005) and fifteenth (2006) reports, it was laid out that keeping in mind the end goal to advance rapid justice, seats of the Supreme Court must be set up in the North-Eastern, Western and Southern parts of the nation. The Committee recommended basic requirements for foundation of a Bench at any rate in Chennai on a trial premise in its 20th (2007), 26th (2008) and 28th (2008) Reports. In the 28th Report of the Standing Committee, it set out the purpose behind positioning of the seats of the Supreme Court in Southern, Western and Eastern parts of the nation as "The Committee's recommendation rests on the premise that it is not possible for the people living in far-flung and remote areas to come to the National Capital for seeking justice for various reasons" ${ }^{19}$

Thus, it is evident that both from the Law Commission Reports and the Reports of Parliamentary Standing Committee, that there have been recommendations to the legislature ever since 1986 about the growing need for the establishment of the benches of the Supreme

$18 I d$.

1928th Parliamentary Standing Committee on Law and Justice Report. 
Court, for reducing the transaction cost of the potential litigant and also of ensuring full access to justice. Also, the serious issue of backlog that the Supreme Court faces, could be considerably reduced by the classification of the Supreme Court into legal and Constitutional division and the establishment of the benches of Supreme Court in the Southern, Western and Eastern part of the country respectively.

\section{Essential reasons for the establishment of the cassation benches of the Supreme Court}

There are innumerable reasons behind the establishment of the benches of the Supreme Court. India is a diverse country with a rich geographical divide. Also, the economic condition at the micro level, highlights nothing much to boast about. In 2012, the Indian government stated that $21.9 \%$ of its population is below its official poverty limit. ${ }^{20}$ Moreover, taking into consideration the International standard, $32.7 \%$ percent of Indians are extremely poor as an income of less than $\$ 1.90$ per day, per head of purchasing power parity is defined as extreme poverty. ${ }^{21}$ Thus, it is essential for providing the right to access to justice guaranteed as a fundamental right to all the citizens, by ensuring that the additional transaction cost of litigation should be minimal. It may be noted that the very purpose of the apex court is to deal with cases involving substantial question of Constitutional law, which has presently taken a back seat and majority of the cases being dealt with are cases which come under the ambit of SLP of civil and criminal matters. Thus, it is necessary to shift the focus back on cases which involve substantial question of law and which will ultimately help in the development of legal jurisprudence. Taking into consideration the aforementioned factors, the essential reasons for the establishment of benches of Supreme Court can be broadly divided into three heads namely (i) wide access to justice (ii) Supreme Court reduced to an ordinary court of appeal (iii) litigation as a measure of well-being.

${ }^{20}$ Data available on https://data.gov.in/catalog/below-poverty-lineindia.

${ }^{21}$ Report on Poverty and Justice - India by The World Bank (2012). 


\section{III.1 Wide access to justice}

When we talk about right of access to justice as a fundamental right, it is imperative to look at the issue of wide access to justice, where anyone who has suffered a violation of a constitutional right, irrespective of his geographical situation or economic condition, i.e., from the poorest villager in the remote areas of Jharkhand or Chhattisgarh to the wealthiest businessman in Mumbai or Delhi, can appear before a bench of the Supreme Court to have their case heard.22 Thus, the very basis of valuing wide access to the Supreme Court is both idealistic and pragmatic. Also, what is meant by wide access to the Supreme Court is the access to all its citizens throughout India. But this does not seem to be the case. While averaging 2006, 2007, 2008, and 2011, the Delhi High Court had the most elevated recurrence of cases disposed off by it and matters appealed to the Supreme Court were to the extent of $9.3 \%$ only. The High Courts of Uttarakhand and Punjab are close to Delhi and have had an appeal rate to the Supreme Court of more than 5\%. All other High Courts, other than Himachal Pradesh (3.2\%) and Bombay $(3.0 \%)$, had an appeal rate of under 3\%. Madras had an appeal rate of only $1.1 \%$ and Orissa less than $1 \%$. The four high courts with the most astounding appeal rates are likewise the four nearest to the Supreme Court in 2011.These high courts generated $34.1 \%$ of the appeals to the Supreme Court, yet catered to just $7.2 \%$ of the aggregate populace. Hence, it can be construed that the removal of these four high courts from the calculation would lead to the conclusion that the correlation between appeal rate and distance from the Supreme Court is practically nonexistent.

Thus, it can be easily interpreted from the table that there is a substantial decrease in the percentage of appeal with growing distance from Delhi. Therefore, the entire concept of wide access to justice is only to cater to the needs of the limited few restricted to people close to Delhi. This is due to the reason that the greater the distance from Delhi, the more the cost of litigation, and due to this reason many potential litigants cannot afford that cost owing to weak financial condition. Orissa, for example, has the lowest

${ }^{22 N i c k}$ Robinson, The Indian Supreme Court and its benches, http:/ / india-seminar.com/2013/642/642_nick_robinson.htm (last visited on April 24, 2017). 
appeal rate, at less than 1 per cent, seemingly the result of a combination of the State's low-income levels and distance from the national capital. ${ }^{23}$

\begin{tabular}{|c|c|c|c|c|c|c|c|}
\hline & 2006 & 2007 & 2008 & 2011 & Average & $\begin{array}{l}\text { Distance } \\
\text { from S. } \\
\text { Ct. }(\mathrm{km})\end{array}$ & $\begin{array}{l}\text { GNP per capita } \\
2010-2011 \text { (Rs) }\end{array}$ \\
\hline $\begin{array}{l}\text { Delhi } \\
\text { Punjab and }\end{array}$ & 6.6 & 9.1 & 10 & 12 & 9.4 & 2 & 150653 \\
\hline Haryana & 6.2 & 8.1 & 6.2 & 8.9 & 7.4 & 260 & $(69737)(94680)$ \\
\hline $\begin{array}{l}\text { Uttaranachal } \\
\text { Himachal }\end{array}$ & 5.2 & 4.9 & 6.2 & 7 & 5.8 & 272 & 66368 \\
\hline Pradesh & 2.9 & 3.1 & 2.7 & 4.3 & 3.3 & 362 & 65535 \\
\hline Bombay & 3.2 & 2.8 & 2.4 & 3.8 & 3.1 & 1395 & 83471 \\
\hline Karnataka & 3.5 & 3.6 & 2.4 & 2.2 & 2.9 & 2073 & 60946 \\
\hline $\begin{array}{l}\text { Andhra Pradesh } \\
\text { National }\end{array}$ & 2.6 & 3.1 & 2.9 & 2.8 & 2.9 & 1506 & 62912 \\
\hline $\begin{array}{l}\text { Average } \\
\text { Madhya }\end{array}$ & 2.4 & 2.6 & 2.5 & 2.7 & 2.6 & & 60972 \\
\hline Pradesh & 2.3 & 2.4 & 2.8 & 2.4 & 2.5 & 800 & 32222 \\
\hline Rajasthan & 3.1 & 2.7 & 2.5 & 1.2 & 2.4 & 572 & 42434 \\
\hline Uttar Pradesh & 2.4 & 2.3 & 2.3 & 2.2 & 2.3 & 693 & 26355 \\
\hline Jharkhand & 1.7 & 2.8 & 2.2 & 2.1 & 2.2 & 1191 & 29786 \\
\hline Gujarat & 1.5 & 1.5 & 1.8 & 3.2 & 2.0 & 932 & 75115 \\
\hline Kerala & 1.5 & 2 & 1.8 & 2.5 & 2.0 & 2574 & 71434 \\
\hline Chattisgarh & 2.1 & 1.5 & 1.2 & 2.8 & 1.9 & 1186 & 41167 \\
\hline Calcutta & 1.5 & 1.8 & 1.7 & 1.7 & 1.7 & 1439 & 48536 \\
\hline Assam & 1.6 & 1.6 & 1.4 & 1.2 & 1.5 & 1805 & 30569 \\
\hline Bihar & 1 & 1.7 & 1.3 & 1.6 & 1.4 & 1026 & 20708 \\
\hline $\begin{array}{l}\text { Madras } \\
\text { Jammu and }\end{array}$ & 0.8 & 1.3 & 1.1 & 1.1 & 1.1 & 2118 & 72993 \\
\hline Kashmir & 1.2 & 0.7 & 1 & 1.2 & 1.0 & 867 & 37496 \\
\hline Orrisa & 0.6 & 0.8 & 1 & 1.2 & 0.9 & 1688 & 40412 \\
\hline \multicolumn{8}{|c|}{$\begin{array}{l}\text { Court to the Supreme Court and the distance of the primary High Court } \\
\text { bench in each jurisdiction to the Supreme Court as well as the GNP per } \\
\text { capita of the state. }\end{array}$} \\
\hline \multicolumn{8}{|c|}{$\begin{array}{l}\text { SoURCE: State-Wise Origin of Supreme Court Appeals }(2006-2008,2011) \\
\text { provided by Supreme Court of India; Court News (2006-2008, 2011); }\end{array}$} \\
\hline \multicolumn{8}{|c|}{ Distances calculated using shortest driving route (in distance) on Google } \\
\hline $\begin{array}{l}\text { Maps from the res } \\
\text { Economics \& Stati } \\
\text { India, Central Stati }\end{array}$ & $\begin{array}{l}\text { tive } \mathrm{H} t \\
\text { cs of re }\end{array}$ & Court & $\begin{array}{l}\text { the } \mathrm{Su} \\
\text { ate Gov }\end{array}$ & eme $\mathrm{C}$ & $\begin{array}{l}\text { ourt; Direct } \\
\text { s, and for A }\end{array}$ & torate of & \\
\hline
\end{tabular}

Fig 1 illustrating the percentage of appeal to the Supreme Court depending on the distance from Delhi $^{24}$

${ }^{23}$ Nick Robinson, Hard to reach: A survey of the Supreme Court's docket finds a court overwhelmed by petitions from those with money and resources, 27 FRONTLINE, Jan. 30- Feb. 12, 2010

${ }^{24}$ Figure available at A QUANTITATIVE ANALYSIS OF THE INDIAN SUPREME COURT'S WORKLOAD by NICK ROBINSON. 
Thus, from the above given data it is perfectly clear that the door of the Supreme Court is accessible only to people close to Delhi and there is very limited accessibility to the people in the southern states as well as those in the north-eastern region. For justice to reach to every nook and corner of the country and for establishing the faith of every individual to the judiciary, it is essential to establish the benches of the Supreme Court according to the recommendations of 229th Law Commission Report. ${ }^{25}$

\section{III.2. Supreme Courtas an ordinary court of appeal}

One of the most pivotal functions of the Supreme Court is to look after cases involving substantial question of Constitutional Law and in the words of Dr. B.R. Ambedkar, to ensure the guarantee of fundamental rights to every individual. ${ }^{26}$ But over the years things have seemed to change. In the year 2007, the three categories of cases that were most prominent among all, were criminal matters (974 decisions), benefit matters (737 decisions), and indirect tax matters (651 decisions). Despite the fact that the court acknowledged 12 percent of matters set before it for normal hearing, the most elevated acknowledgment rates were for direct tax matters (20 percent) and arbitration (19 percent).On the other hand, just around 1 percent of the court's standard hearing choices involve public interest litigation (PIL). When we analyze the observational information in the previous couple of years, the percentage of admission matters that are SLP's (full form when using for the first time) has expanded from $78-82 \%$ in the 1990 s to $83-86 \%$ in the period 2005-2011.However, the bigger change in the Court's admission has come in connection to writ petitions which showed a drop from $4-7 \%$ to $1-2 \%$ of the docket amid similar periods. Attributable to the extensive number of SLP's, the court is confronting a genuine excess circumstance. As indicated by the information accessible, the Supreme Court of India disposed off 47,424 cases in the year 2015, in contrast with 45,042 in 2014 and 40,189 in the year 2013.But, even after such exertion of quick case

\footnotetext{
25 Supranote 18.

26 Supra note 3.
} 
disposal, the backlog in the Supreme Court still stands at a staggering figure of 59,468 cases as of February 2016.27

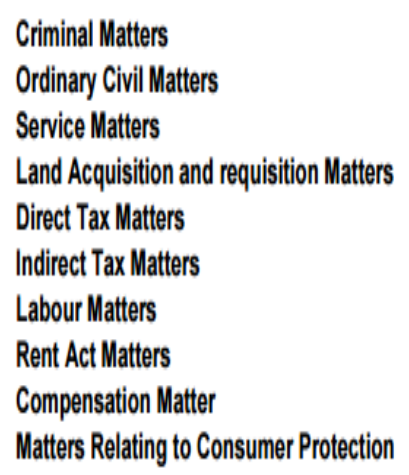

$\begin{array}{rrrrrrrl}2005 & 2006 & 2007 & 2008 & 2009 & 2010 & 2011 & \text { Average } \\ 25.5 & 23.3 & 25.3 & 26.1 & 25.5 & 25.6 & 25.9 & 25.3 \\ 13.0 & 14.5 & 14.4 & 14.4 & 14.4 & 14.8 & 14.4 & 14.3 \\ 14.0 & 15.3 & 12.9 & 12.6 & 13.0 & 12.9 & 14.2 & 13.6 \\ 5.1 & 5.9 & 5.3 & 5.6 & 6.2 & 9.0 & 8.3 & 6.5 \\ 2.5 & 3.4 & 4.7 & 5.8 & 7.4 & 5.7 & 6.2 & 5.1 \\ 6.2 & 5.3 & 6.2 & 4.0 & 4.1 & 3.4 & 3.4 & 4.6 \\ 4.4 & 5.6 & 4.2 & 3.8 & 3.9 & 3.8 & 3.2 & 4.1 \\ 3.9 & 3.8 & 4.0 & 3.5 & 3.0 & 3.0 & 2.8 & 3.4 \\ 1.9 & 2.1 & 2.6 & 3.5 & 3.0 & 2.7 & 2.9 & 2.7 \\ 4.2 & 2.2 & 2.1 & 2.2 & 2.4 & 2.4 & 1.8 & 2.5\end{array}$

Fig 2 demonstrates the disposal of admission matter by subject category ${ }^{28}$

\begin{tabular}{|r|r|r|r|r|r|r|r|r|r|r|}
\hline & \multicolumn{3}{|c|}{ Institution } & \multicolumn{3}{|c|}{ Disposal } & \multicolumn{3}{c|}{ Pendency } \\
\hline YeAR & Admission & Regular & Total & Admission & Regulat & Total & Admission & Regular & Total \\
\hline 2008 & 63,346 & 7,006 & 70,352 & 61,219 & 6,240 & 67,459 & 30,087 & 19,732 & 49,819 \\
\hline 2009 & 69,171 & 7,980 & 77,151 & 64,282 & 6,897 & 71,179 & 34,976 & 20,815 & 55,791 \\
\hline 2010 & 69,456 & 8,824 & 78,280 & 71,867 & 7,642 & 79,509 & 32,565 & 21,997 & 54,562 \\
\hline 2011 & 68,020 & 9,070 & 77,090 & 67,131 & 6,002 & 73,133 & 33,454 & 25,065 & 58,519 \\
\hline 2012 & 68,887 & 8,030 & 76,917 & 64,682 & 4,062 & 68,744 & 37,659 & 29,033 & 66,692 \\
\hline 2013 & 68,478 & 8,264 & 76,742 & 70,385 & 6,700 & 77,085 & 35,752 & 30,597 & 66,349 \\
\hline 2014 & 67,965 & 13,618 & 81,583 & 68,352 & 14,661 & 83,013 & 35,284 & 29,635 & 64,919 \\
\hline (Nov) & & & & & & & & & \\
\hline
\end{tabular}

Fig 3 illustrating the backlog situation faced by the court ${ }^{29}$

27 Supranote 6.

${ }^{28}$ Figure available at A QUANTITATIVE ANALYSIS OF THE INDIAN SUPREME COURT'S WORKLOAD by NICK ROBINSON.

${ }^{29}$ The Supreme Court of India, Annual Report 2014-2015. 
Thus, if we go into the details of the table we find that approximately $53 \%$ of all the matters are related to criminal, ordinary civil and service matters which most often does not involve substantial question of law and there are very few cases in respect of the interpretation of the Indian Constitution that are being heard by the Court. Hence, to go by the recommendations of the 229th Law Commission Report, the establishment of the four cassation benches of the Supreme Court is the need of the hour as it will not only shift the burden of solving the criminal and civil matters to cessation benches, but will also shift the focus back to looking after the cases involving substantial question of law. It will also help to reduce the backlog of the cases owing to the scarcity of the cases.

\section{III.3. Poor judge to population ratio and the reduced size of the bench}

The inordinate delay in the judgment and the ever-increasing backlog of cases in the Supreme Court, has often been attributed to the poor Judge to population ratio. In the case of All India Judges' Association v. Union of India ${ }^{30}$, it was observed that without any further delay it was necessary to increase the number of judges in the Supreme Court. With reference to this, it was noted that "time has come for protecting one of the pillars of the Constitution, namely, the judicial system, by directing increase, in the first instance, in the Judge strength from the existing ratio of 10.5 or 13 per 10 lakh people to 50 Judges per 10 lakh people"31; Also in the case of P. Ramchandra Rao v. State of Karnataka32, the poor judge population ratio was held as the root cause for delay of justice in the nation. Moreover, the Law Commission, in its 120th Report: "Manpower Planning in Judiciary: A Blue Print" 33 recommended that there was strong justification to increase the then existing ratio from 10.5 judges per million to at least 50 judges per million of Indian population. This was after a

\footnotetext{
${ }^{30}$ All India Judges' Association v. Union of India, (2002) 4 SCC 247.

${ }^{31}$ Id.

32(2002) 4 SCC 578.

${ }^{3}$ Supra note 14.
} 
comparative study of judge to population ratio in different jurisdictions, which stood as in 1987, as illustrated in the figure $4^{34}$ :

The scarcity of judges over a period of time has been very detrimental to the administration of justice in the country. Article $145^{35}$ which talks about the sitting of Constitutional bench for determination of cases involving substantial question of constitutional law, has been reduced merely to a text. In the recent

\begin{tabular}{|l|l|}
\hline Country & Judges per million \\
\hline Australia & 41 \\
\hline Canada & 75 \\
\hline England & 51 \\
\hline USA & 107 \\
\hline India & 10.5 \\
\hline
\end{tabular}

past, most cases have been decided by the two-judge bench. In Lily Thomas v. Union of India EOrs. ${ }^{36}$ wherein the Supreme Court declared null and void Section 8(4) of the Representation of the People Act, 1951was decided by a division bench. Essentially, the decisions on vital policy matters are chosen by a seat of two judges of the Court. In the 2G Spectrum Case, a seat of two judges recommended a national policy for disposing off all public resources by public auctioning. Subsequently, just a couple of instances of established and national significance have been chosen by the Supreme Court and that too with a seat smaller than the one which the Constitution orders. All this has a direct impact on the judicial system of the country, leading to poor outcomes.

Thus, if we look closely at the recommendations of the Law Commission over a period of time, it not only proposes to solve the backlog of cases in the country, but also provides room for the Supreme Court, to act as the guardian of the Constitution and fulfill the requirements of a Constitutional court. The 229th Law Commission Report ${ }^{37}$ provides for a stable ground for the establishment of the same.

${ }^{34} I d$.

35INDIA CONST. art. 145.

36(2013) 7 SCC 653.

37 Supra note 16. 


\section{III.4. Litigation as a Measure of Well-Being}

The paper "Litigation as a Measure of Well-Being" by Sital Kalantry, Theodore Eisenberg and Nick Robinson, ${ }^{38}$ which is an empirical study of litigation in India, fills in as a supply hotspot for generous proof that higher suit rates are a measure or are a characteristic outcome of financial advancement and enhanced prosperity of people. The report has been analyzed to assess monetary and noneconomic prosperity together, as measured by the Human Development Index.

\begin{tabular}{|c|c|c|c|c|c|c|c|c|c|}
\hline & $\begin{array}{c}\text { State } \\
\text { Aboreviation }\end{array}$ & $\begin{array}{l}\text { Filings per } \\
1000 \text { Persons }\end{array}$ & $\begin{array}{c}\text { GDP per } \\
\text { Capita (rupees) }\end{array}$ & HDI & $\begin{array}{l}\text { Literacy Rate } \\
2011(\%)\end{array}$ & $\begin{array}{c}\text { Population } 2011 \\
\text { (millions) }\end{array}$ & $\begin{array}{l}\text { Population } 2001 \\
\text { (millions) }\end{array}$ & $\begin{array}{l}\text { Population per } \\
\text { Sq Kilometer }\end{array}$ & $\begin{array}{c}\text { Years to Clea } \\
\text { Backlog } \\
\end{array}$ \\
\hline Andhra Pradesh & AP & 3.6 & 37,126 & 0.473 & 67.7 & 84.7 & 76.2 & 308 & 1.5 \\
\hline Arunachal Pradesh & $A R$ & 0.4 & 36,763 & $n / a$ & 670 & 1.4 & 1.1 & 17 & 3.1 \\
\hline Assam & AS & 1.2 & 21,266 & 0.444 & 73.2 & 31.2 & 26.7 & 397 & 23 \\
\hline Bthar & BR & 0.5 & 11,573 & 0.367 & 63.8 & 100.8 & 83.0 & 1102 & 5.8 \\
\hline Chandigarh & $\mathrm{CH}$ & 9.2 & 97,723 & n/a & 86.4 & 1.1 & 09 & 9252 & 2.4 \\
\hline Chhatisgarh & CT & 1.7 & 27,547 & 0.358 & 71.0 & 25.5 & 20.8 & 189 & 2.4 \\
\hline Dellhi & $\mathrm{DE}$ & 5.7 & 86,119 & 0.750 & 86.3 & 16.8 & 13.9 & 11297 & 1.9 \\
\hline Goa & GA & 7.6 & 102,590 & 0.617 & 87.4 & 15 & 1.3 & 394 & 15 \\
\hline Gujarat & GJ & 3.7 & 47,052 & 0.527 & 793 & 60.4 & 50.7 & 308 & 3.2 \\
\hline Haryana & HR & 5.4 & 55,749 & 0.552 & 76.6 & 25.4 & 21.1 & 573 & 1.7 \\
\hline Himachal Pradesh & HP & 7.5 & 40,968 & 0.652 & 83.8 & 6.9 & 6.1 & 123 & 1.3 \\
\hline Jammu \& Kashenir & JK & 39 & 25,628 & 0.529 & 68.7 & 12.5 & 10.1 & 124 & 1.4 \\
\hline Jharkhand & JH & 0.5 & 22,235 & 0.376 & 67.6 & 33.0 & 26.9 & 414 & 2.7 \\
\hline Karnataka & KA & 4.9 & 39,331 & 0.519 & 75.6 & 61.1 & 52.9 & 319 & 1.9 \\
\hline Kerala & $\mathrm{KL}$ & 8.6 & 44,243 & 0.790 & 93.9 & 33.4 & 31.8 & 859 & 15 \\
\hline Madhya Pradesh & MP & 2.8 & 20,507 & 0.375 & 706 & 726 & 60.3 & 236 & 1.0 \\
\hline Maharashtra & MH & 3.5 & 53,468 & 0.572 & 82.9 & 112.4 & 969 & 365 & 2.5 \\
\hline
\end{tabular}

Fig $5^{\text {sy: }}$

Accordingly, ensuring access to justice, which incorporates furnishing people with a sensible opportunity to vindicate rights through cases, may oblige governments to guarantee financial opportunity and social rights to people. Gross domestic product development alone does not guarantee all people a reasonable chance to vindicate their rights. ${ }^{40}$ Thus, in a country like India, where the poverty rate is high, the association between non-

38 Sital Kalantry et. al., Litigation as a Measure of Well-being, http:/ / chicagounbound.uchicago.edu/cgi/viewcontent.cgi?article $=5037 \&$ context=journal_articles(Last visited Apr. 27, 2017).

39 Sital Kalantry et. al., Litigation as a Measure of Well-being, http:/ / chicagounbound.uchicago.edu/cgi/viewcontent.cgi?article $=5037 \&$ context=journal_articles(Last visited Apr. 27, 2017).

40 Supra note 40 . 
economic well-being, like literacy and litigation rates, is less widely acknowledged.

Hence, this enhances the need for the establishment of the Benches of the Supreme Court, which will provide a wide access to all the citizens.

\section{Constitutional requirement for the establishment of the benches of the Supreme Court}

The 95 ${ }^{\text {th }}$ Law Commission Report 41 put forth that, for bringing into effect the recommendation of the division of the Supreme Court into Constitutional and Legal Division, an amendment of the Constitution would be necessary, i.e. an ordinary legislation, vide article 246(1) read with Entry 77 of the Union List or statutory rules. However, the recommendations of the 229th Law commission report ${ }^{42}$ is more feasible, as the foremost advantage of setting up of benches in the manner prescribed in the 229th report, is its effectiveness without any delay, since the constitution of benches is a matter within the purview and jurisdiction of the Supreme Court itself, under the Supreme Court Rules 1966, 6 Order VII, Supreme Court Rules 1966.43

Moreover, a plenary reading of Article $130^{44}$ of the Constitution, is wide enough to provide constitutional mandate for the establishment of the Benches of the Court. Article 130 reads as: "The Supreme Court shall sit in Delhi or in such other place or places, as the Chief Justice of India may, with the approval of the President, from time to time, appoint." Though Article 130 cannot be construed as casting a mandatory obligation on the Chief Justice of India to appoint place or places other than Delhi as the seat of the Supreme Court45, it is an enabling provision which empowers the Chief Justice of India, with the approval of the President, to do the same.

\footnotetext{
41Supra note 11.

42 Supra note 17.

43Supreme Court Rules available at http://supremecourtofindia.nic.in/ Supreme\%20Court\%20Rules, \%202013.pdf (Last visited Apr. 27, 2017).

${ }^{44}$ INDIA CONST. art. 143.

${ }^{45}$ Supra note 44.
} 


\section{Judicial Development}

In the recent case of V. Vasantha Kumarv. H.C. Bhatia and Ors., ${ }^{46}$ the Supreme Court referred the matter to a Constitutional Bench for decision on the National Court of Appeal. However, the first reference to the National Court of Appeals was made by the Hon'ble Supreme Court in the year 1986 where the court in the case of Bihar Legal Support Society v. The Chief Justice of India EAnr., ${ }^{47}$ observed that the Supreme Court was never expected to be an ordinary court of appeal against the decisions of the High Court and other subordinate Courts and it would be desirable to set up a National Court of Appeal which would entertain appeals by special leave from the decisions of the High Courts and the Tribunals. ${ }^{48}$ In the case of Vasantha Kumar, ${ }^{49}$ the Court while referring the matter to the Constitutional Bench, laid down 11 issues for the bench to consider. The issues raised can be summarized as: 1)whether delay in disposal of cases violates the fundamental right of access to justice 2) whether increase in the number of judges serve as a solution to delay in disposal 3) whether the division of the Court serve as a solution 4) whether distance from Delhi serve as a deterrent in access to justice 5) whether Benches of the Supreme Court could serve as a solution to the distance problem 6) whether the Supreme Court of India been exercising jurisdiction as an ordinary court of appeal on facts and law, in regard to routine cases of every description 7) Is the huge pendency of cases in the Supreme Court, caused by the Court not restricting its consideration, as in the case of the Apex Courts of other countries, to Constitutional issues, questions of national importance, differences of opinion between different High Courts, death sentence cases and matters entrusted to the Supreme Court by express provisions of the Constitution? 8) Is there a need for establishing a National Court of Appeals and whether setting up of the National Court of Appeals is going to provide access to justice to all. 9) If four regional Courts of Appeal are established, in the Northern, Southern, Eastern and Western regions of the Country,

\footnotetext{
${ }^{46}$ V. Vasanth Kumar v. H. C. Bhatia, (2016) 7 SCC 686.

47Bihar Legal Support Society,1987 SCR (1) 295.

48 Id

${ }^{49}$ Supra note 46.
} 
would this not satisfy the requirement of 'access to justice' to all litigants from every part of the country? 10) As any such proposal would need an amendment to the Constitution, would the theory of 'basic structure' of the Constitution be violated 11)In view of cases pending in the Supreme Court of India, in the High Courts and Trial Courts, would it not be part of the responsibility and duty of the Supreme Court of India to examine through a Constitution Bench, the issue of divesting the Supreme Court of about $80 \%$ of the pendency of cases of a routine nature, so that the Supreme Court may regain its true status as a Constitutional Court?50

\section{Conclusion}

Thus, as clearly highlighted in the paper, the door of the Supreme Court is accessible only to people close to Delhi and there is very limited accessibility to the people in the southern states as well as those in the north-eastern region. Moreover, because of the poor judge to population ratio and the type of cases admitted in the Supreme Court, the stature of the Supreme Court has been reduced to an ordinary court of appeal, which in itself is directly related to the well-being of the people. The law commission from time to time, as well as the parliamentary standing committees have tried to address the issue by various recommendations, so that the purpose for which the Supreme Court was established can be fulfilled. There is a greater impetus on issues involving substantial question of law rather than spending time on criminal and service matters which can be handled by an alternate Court with better precision and time dedication and which subsequently will lead to the reduction in the backlog.

Thus, looking at the various Law Commission reports and analyzing the immediate need for the reform of the judicial system it is to be noted that the recommendations set forth in the 229 th Law Commission report should be taken into consideration by the Parliament. This is all the more important for the establishment of Right of access to Justice provided by the Constitution.

${ }^{50} I d$. 